\title{
Konsep Ecotourism Masa Transisi Pandemi Covid-19 di Desa Wisata Kerajinan Bambu Brajan Yogyakarta.
}

\author{
Yayu Rubiyanti \\ Program Studi Desain Interior, Fakultas Seni Rupa, Institut Seni Indonesia Yogyakarta \\ Email: yayu.rubiyanti@isi.ac.id
}

\begin{abstract}
Abstrak
Situasi yang tidak menentu yang diakibatkan oleh pandemi global COVID-19 serta adanya kebijakan Pembatasan Sosial Berskala Besar menyebabkan masyarakat membatasi serta mempersempit aktivitas sosial yang berkaitan dengan kegiatan luar rumah. Pembatasan sosial ini menyebabkan tekanan yang tinggi pada masyarakat, baik dari sisi sosial maupun ekonomi. Mulai diberlakukannya masa transisi menuju normal baru disambut gembira oleh masyarakat dengan cara melakukan berbagai aktivitas di luar rumah meskioun dengan protokol yang ketat. Tujuan rekreasional seperti jogging, bersepeda menjadi trend setelah masa transisi normal baru diberlakukan. Jenis wisata yang relatif mampu mengakomodir kebiasaan baru masyarakat tersebut adalah wisata ecotourism. Ecotourism dinilai mampu menjawab kebutuhan masyarakat untuk beraktivitas di luar ruangan sekaligus menyediakan berbagai fasilitas yang memenuhi batasanbatasan dalam protokol kesehatan. Salah satu destinasi wisata yang memiliki potensi untuk dikembangkan sebagai wisata ecotourism adalah Desa Wisata Brajan. Desa ini berlokasi tidak terlalu jauh dari pusat kota, sehingga relatif mudah dijangkau.

Tujuan penelitian ini adalah menghasilkan kriteria konsep wisata berwawasan ekologis sesuai dengan potensi-potensi yang dimiliki Desa Wisata Bambu Brajan Yogyakarta. Penelitian ini sangat penting dilakukan karena pada masa adaptasi baru transisi pandemi COVID-19 seperti terjadi saat ini juga memunculkan peluang untuk meningkatkan kunjungan wisata. Penelitian ini menggunakan metode design thinking, data penelitian didapatkan dari hasil observasi lapangan serta wawancara. Hasil penelitian yang ditargetkan adalah kriteria model ruang Desa Wisata Brajan yang sesuai dengan kaidah ecotourism pada masa transisi pandemi covid-19.
\end{abstract}

Kata kunci: Desa Wisata, Ecotourism, Masa Transisi Pandemi COVID-19

\begin{abstract}
The uncertain situation caused by the global COVID-19 pandemic as the large-scale social restrictions policy has caused people to limit and narrow down social activities related to outdoor activities. This social limitation causes high pressure on society, both from the social and economic side. The community welcomes the commencement of the transition to normalcy by carrying out various outdoor activities, although with strict protocols. Recreational goals such as jogging, cycling became a trend after the new normal transition period was implemented.
\end{abstract}

The type of tourism that is relatively able to accommodate the new habits of the community is ecotourism. Ecotourism can answer people's needs for outdoor activities while providing various facilities that meet health protocols. One tourist destination that has the potential to be developed as ecotourism tourism is Brajan Tourism Village. This village is located not too far from the city center, so it is relatively easy to reach.

The purpose of this research is to produce criteria for an ecological concept of tourism following the potentials of the Brajan Bamboo Tourism Village. This research is important during the new adaptation period since the COVID-19 pandemic is currently happening, thus it provides opportunities to increase tourist visits. This study uses the design thinking method, research data 
obtained from field observations, and interviews. The results of the research are criteria for the concept of a spatial model design for the Village by the principles of ecotourism during Covid-19 pandemic transition period.

Keywords: Tourism Village, Ecotourism, The Transition Period of the COVID-19 Pandemic

\section{Pendahuluan}

Desa Wisata Brajan merupakan salah satu desa wisata cinderamata yang terletak di area pinggiran barat Sleman tepatnya di Kecamatan Minggir, Sleman, DIY. Sama seperti desa wisata lainnya, Desa Wisata Brajan juga memiliki ikon khas kebanggaannya yaitu Bambu. Bambu menjadi kekuatan utama desa ini bahkan dapat dibilang bambulah salah satu alasan utama diresmikannya desa wisata ini pada tahun (lupa). Hampir seluruh warga Desa Wisata Brajan bekerja menjadi pengrajin bambu secara mandiri maupun terikat dengan showroom yang berada di area desa. Terdapat 5 showroom kerajinan bambu yang berdiri di Desa Wisata Brajan. Yang pertama didirikan adalah showroom Prink Mas, adalah cikal bakal produksi kerajinan bambu di Desa Brajan. Prink berarti bambu dan Mas berarti emas. Pengelola berangkat dari keinginan mereka untuk bagaimana mengubah bambu menjadi emas sehingga pekerjaan pengrajin bambu tidak lagi dikonotasikan sebagai pekerjaan rendahan penuh keterpaksaan. Mulanya, Desa Brajan hanya memproduksi kerajinan bambu fungsional dengan anyaman sederhana seperti besek dan cething. Kian lambat laun, desain yang diproduksi dan dijual di pasaran mulai mengikuti berkembangnya zaman. Desain besek dan cething yang sederhana kini telah lebih kuat serta dipoles dengan warnawarna dan aksesoris menarik. Produk keseharian seperti tudung saji, kap lampu, aksesoris meja, sampai dompet dan topi berbahan bambu juga tersedia. Kekhasan produk-produk kerajinan menarik wisatawan lokal, nasional, sampai internasional untuk datang dan memesan produkproduk Desa Wisata Brajan.

Kesuksesan Desa Wisata Brajan membuat sejumlah pemerintah dari berbagai daerah tertarik untuk membawa warga-warga desa berkembang di daerahnya untuk melakukan studi mengenai bagaimana mengolah sumber daya alam milik sendiri menjadi buah penghasilan para warganya khususnya mengolah bambu menjadi kerajinan. Kegiatan studi menjadi kegiatan yang dapat dikatakan rutin dijalankan. Peserta studi tidak hanya berasal dari warga desa berkembang lain tetapi juga dari kalangan wisatawan dan institusi sekolah seperti sekolah dasar sampai universitas. Peserta studi dapat memilih seberapa lama waktu belajar yang dibutuhkan. Ada kunjungan studi yang dilakukan tidak lebih dari sehari seperti kunjungan dari sekolah tetapi umumnya kegiatan studi dilakukan selama beberapa hari mengingat proses pembuatan kerajinan bambu yang membutuhkan waktu. Peserta studi disediakan penginapan di dalam desa oleh warga secara sukarela yang biasanya juga pemilik showroom. Dalam kunjungannya, para wisatawan baik yang hanya berkunjung membeli kerajinan sampai yang melakukan studi disuguhkan dengan lanskap pedesaan yang asri, sejuk, dan masih hijau. Objek daya tarik yang banyak diminati masyarakat selain showroom kerajinan bambu adalah taman bunga dan pemancingan. Terdapat banyak aktivitas wisata di taman bunga yang ditawarkan pada para wisatawan termasuk di antaranya outbond, melihat atraksi menggarap sawah, dan belajar menanam padi. Semua data fasilitas, daya tarik, dan kegiatan wisata yang tersedia di Desa Wisata Brajan dapat diakses melalui laman-laman wisata. Dinas pariwisata setempat telah menyediakan rambu-rambu pemandu jalan bagi para pengunjung. Sebelum masuk kawasan desa, pengunjung disuguhkan dengan visual pemandangan sawah yang indah dan menyegarkan. Para petani sedang menggarap sawah bersama burungburung kuntul berdiri menemani bersama mereka berdiri latar pegunungan hijau Kabupaten Kulon Progo.

Pada perkiraan awal tahun 2020, berbagai sektor ekonomi di Indonesia termasuk di antaranya sektor pariwisata dan ekonomi kreatif dilanda kerugian akibat pandemi COVID-19. Pemerintah mewajibkan masyarakat untuk menjalankan protokol kekarantinaan kesehatan Pembatasan Sosial Berskala Besar (PSBB). Artinya masyarakat bersama lembaga-lembaga diwajibkan untuk melakukan karantina rumah, rumah sakit, dan wilayah. Seluruh kegiatan sehari-hari seperti 
sekolah dan bekerja dilakukan dari dalam. Masyarakat dihimbau untuk membatasi untuk tidak bepergian ke tempat umum dalam rangka pencegahan penularan virus COVID-19. Akibat pandemi, jumlah pengunjung wisata di Desa Wisata Brajan menurun drastis yang berimbas pada anjloknya pemasukan warga dan desa. Jumlah pengunjung yang hanya ingin membeli kerajinan turun drastis. Kegiatan studi juga ditutup total mengikuti himbauan pemerintah daerah.

Setelah berada di kondisi puncak dari pandemi, pemerintah menerapkan masa PSBB transisi. Pada masa ini, masyarakat diberi kelonggaran dalam berkegiatan sosial dan ekonomi secara bertahap tanpa melupakan kewajiban menerapkan protokol kesehatan pencegahan penularan virus COVID19. Protokol kesehatan yang dimaksud sesuai dengan Keputusan Menteri Kesehatan Republik Indonesia Nomor HK.01.07/MENKES/382/2020 (Handayani, Hadi, Isbaniah, Burhan, \& Agustin, 2020) yaitu menjaga kebersihan tangan secara teratur, menggunakan masker, menjaga imun dengan cukup istirahat dan olahraga, serta menjaga jarak minimal satu meter. Masyarakat diharapkan dapat produktif tetapi tetap sehat secara jasmani dan rohani. Imbauan pemerintah untuk tetap sehat dengan melakukan kegiatan fisik dalam rangka menjaga imun dan kesehatan ditambah dengan tetap menjaga jarak disambut baik oleh masyarakat mengingat masyarakat sudah lama dan jenuh untuk berada di dalam rumah. Olahraga atau sekedar beraktivitas di areal terbuka menjadi tren. Tren baru ini dapat menjadi peluang bagi para pengelola tempat wisata khususnya yang berkonsep luas dan terbuka.

Di luar potensi dan peluang yang sudah ada terdapat beberapa masalah atau kelemahan pada pengelolaan Desa Wisata Brajan. Pertama, pada segi ketersediaan komoditas bambu, area yang dapat digunakan untuk ditanami bambu semakin sedikit digeser kebutuhan masyarakat akan kebutuhan lain seperti tempat tinggal. Penanaman tanaman bambu yang tidak tepat berimbas pada kualitas bambu yang menjadi menurun. Identitas bambu Desa Wisata Brajan kini hanya sebatas hasil produksi tetapi bukan komoditas tanaman bambu. Kelemahan pengelolaan tanah juga ada pada penataan lingkungan desa yang masih apa adanya mengikuti tatanan rumah-rumah warga. Sehingga kesan khas desa wisata Indonesia belum terasa secara maksimal. Pengelolaan unsurunsur wisata seperti objek juga menemukan masalah pada sistem pengelolaannya. Akhirnya, peminat objek wisata seperti taman bunga menjadi turun. Penyambutan pengunjung mengalami kendala akibat kurangnya sumber daya manusia karena semua warga fokus pada produksi kerajinan.

Konsep ecotourism dinilai tepat dan cocok untuk menjawab tantangan dan peluang yang hadir akibat pandemi COVID-19 ini walaupun dapat dikatakan dari awal Desa Wisata Brajan telah menerapkan konsep ecotourism karena berangkat dari pemanfaatan ketersediaan tanaman bambu milik sendiri. Kelestarian lingkungan desa yang menjadi kekuatan desa secara turun temurun dijaga walaupun skalanya tidak sebesar desa wisata yang berfokus pada keindahan alam dibanding cinderamata. Banyak manfaat yang didapatkan dari pengelolaan desa wisata yang berfokus pada konsep ecotourism yang menjaga keotentikan alam dan komunitas dengan menggunakan prinsip keberlanjutan (Jones, 2008). Ketersediaan lahan bambu milik desa atau pribadi menghemat biaya produksi kerajinan bambu, membuat kegiatan studi dapat dilakukan lebih dalam dan menyeluruh, dan menumbuhkan daya tarik masyarakat mengenai bambu. Lahan bambu dapat dijadikan sebuah objek wisata baru untuk aktivitas bersepeda, jalan-jalan, dan berfoto. Studi dapat dimulai dari bagaimana cara menanam tanaman bambu, cara pengelolaannya, sampai bagaimana cara pengelolaan limbah dari produksi kerajinan bambu itu sendiri. Penyediaan dan pengelolaan potensi alam dan area terbuka dapat menghadirkan kembali kegiatan wisata yang sudah tidak diminati, seperti outbond, atraksi menggarap sawah, belajar menanam tanaman, dan lain-lain. Hasil bambu yang berlebih dapat dijadikan sebagai material bangunan atau sekadar sebagai penghias bangunan. Identitas bambu dari Desa Wisata Brajan dapat lebih terasa.

Pengembangan konsep ecotourism pada Desa Wisata Brajan perlu dirancang sebaik mungkin mempertimbangkan keberlangsungan ekonomi warga. Penutupan atau pembatasan area perlu dirancang seefektif mungkin agar tidak mengganggu kegiatan produksi maupun transaksi jual beli kerajinan bambu yang notabene menjadi penghasilan utama bagi warga Desa Wisata Brajan. Hal 
tersebut mengingat Desa Wisata Brajan masih aman dari penularan virus COVID-19. Warga khawatir kepada pihak pengelola pengembangan desa tetapi di sisi lain sumber daya manusia lokal tidak cukup untuk melakukan pengembangan sendiri. Beberapa warga yang telah lanjut usia memilih untuk tidak melakukan pembangunan karena telah merasa cukup dengan kondisi saat ini. Desa Wisata Brajan yang tidak mendapat pemasukan ditambah kondisi pandemi yang memang menyulitkan segala pihak membuat pihak pengelola desa tidak dapat mengembangkan atau sekadar mengelola desa sendirian. Ditambah saat ini, pemerintah memilih berfokus pada penyediaan bantuan kepada warga.

\section{Metode}

Metode yang digunakan dalam penelitian ini adalah metode penelitian kualitatif deskriptif. Fokus dari penelitian ini adalah memaparkan data yang telah diolah menggunakan metode design thinking. Hasil dari data tersebut adalah strategi pengembangan desa berupa kriteria desa wisata yang menerapkan ecotourism.

Pengumpulan data dalam penelitian ini menggunakan dua jenis metode, yaitu: (1) Observasi, dengan cara peneliti turun langsung ke lapangan untuk mengamati aktivitas warga terutama yang berkaitan dengan wisata di Desa Brajan. Peneliti melakukan beberapa metode observasi yang diantaranya adalah merekam/memotret/mencatat perilaku dan aktivitas di dalam lokasi penelitian, yang dalam hal ini peneliti bertindak sebagai non-partisipan, (2) Wawancara, yaitu melakukan penggalian pada person yang dipandang mempunyai peran baik secara langsung maupun tidak langsung pada aktivitas wisata di Desa Brajan.

Terdapat empat partisipan yang didalami infonya oleh peneliti, yang dua di antaranya adalah pengurus desa dan/atau penyedia layanan wisata, serta dua yang lain adalah pengunjung wisata di Desa Brajan. Secara rinci identitas partisipan (nama disamarkan) dapat dilihat pada tabel sebagai berikut :

Tabel 2 Identitas Partisipan

\begin{tabular}{|c|l|c|l|l|}
\hline \multicolumn{5}{|c|}{ (Sumber : Pribadi 2020) } \\
\hline No & Nama & Usia & Jenis Kelamin & $\begin{array}{c}\text { Peran Tabel 1 Identitas } \\
\text { Partisipan }\end{array}$ \\
\hline 1 & A & 55 th & Laki-laki & Warga/Pengurus Desa \\
\hline 2 & B & 50 th & Laki-laki & Penyedia layanan wisata \\
\hline 3 & C & 20 th & Perempuan & Pengunjung \\
\hline 4 & D & 20 th & Laki-laki & Pengunjung \\
\hline
\end{tabular}

\section{Pembahasan}

Design thinking adalah sebuah metode pendekatan yang berorientasi pada kebutuhan sebuah kondisi. Design thinking membutuhkan kepekaan dan empati lebih dengan pendekatan yang lebih komprehensif dan integratif. Metode pendekatan ini memiliki lima buah tahapan yang berupa discovery, interpretation, ideation, experimentation, dan evolution. Kelima tahapan tersebut bertumpu pada data-data yang telah didapatkan pada proses discovery dan interpretation sehingga tahapan tersebut menjadi sebuah tahap yang cukup vital. Pada penelitian ini, penulis hanya menggunakan tiga buah tahap dari Design thinking : discovery, interpretation, dan ideation. 


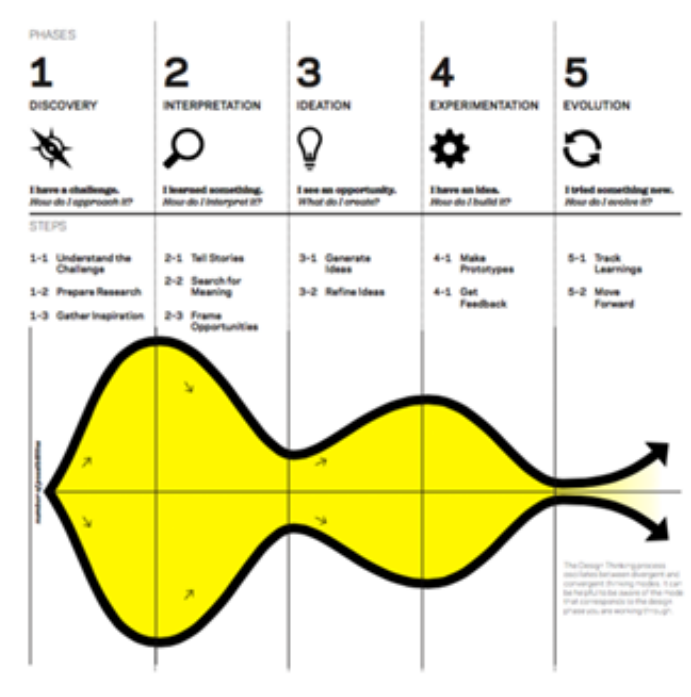

Gambar 1 Diagram Fase Pola Design Thinking. (Sumber : IDEO, 2013)

Design thinking adalah sebuah metode pendekatan yang berorientasi pada kebutuhan sebuah kondisi. Design thinking membutuhkan kepekaan dan empati lebih dengan pendekatan yang lebih komprehensif dan integratif. Metode pendekatan ini memiliki lima buah tahapan yang berupa discovery, interpretation, ideation, experimentation, dan evolution. Kelima tahapan tersebut bertumpu pada data-data yang telah didapatkan pada proses discovery dan interpretation sehingga tahapan tersebut menjadi sebuah tahap yang cukup vital. Pada penelitian ini, penulis hanya menggunakan tiga buah tahap dari Design thinking : discovery, interpretation, dan ideation.

\subsection{Discovery}

Discovery merupakan tahap pertama yaitu untuk mendefinisikan dan memahami suatu persoalan dari fakta-fakta mengenai objek yang akan dirancang. Kemudian setelah itu disimpulkan dan nantinya diidentifikasi hingga diformulasikan menjadi kalimat tanya. Pada tahap pertama ini, dilakukan pengumpulan data dengan cara wawancara dan observasi lapangan di Desa Wisata Brajan. Terdapat empat partisipan yang didalami infonya oleh peneliti, yang dua di antaranya adalah pengurus desa dan/atau penyedia layanan wisata, serta dua yang lain adalah pengunjung wisata di Desa Brajan. Dari hasil wawancara dan observasi lapangan tersebut, didapatkan fakta mengenai kondisi Desa Wisata Brajan khususnya pada masa pandemi COVID-19 saat ini.

\subsection{Interpretation}

Interpretation merupakan tahapan proses menterjemahkan dan menafsirkan objek hingga membentuk suatu pandangan yang akan melahirkan ide. Pada tahap ini, dilakukan inerpretasi menggunakan analisis SWOT sehingga mendapatkan gambaran yang lebih fokus dan detail tentang potensi yang dapat didayagunakan untuk pengembangan konsep desain ecotourism di Desa Wisata Brajan. Parameter yang digunakan untuk mengidentifikasi potensi Desa Wisata Brajan adalah dengan unsur-unsur dalam bidang disiplin manajemen. Sesuai dengan diagram yang dikembangkan oleh Ishikawa (Liliana, 2016) terdapat beberapa unsur dalam manajemen yang dapat dijadikan pedoman dalam menganalisa suatu problem. Beberapa perbedaan penyebutan dan tekanan di antara para pengguna diagram ini terus berkembang sesuai dengan kebutuhan analisanya. Berdasar diagram tersebut peneliti kemudian memilih unsur-unsur yang dianggap paling relevan untuk digunakan dalam identifikasi dan analisa potensi di Desa Wisata Brajan, yaitu Sumber Daya Manusia (Man), Sumber Pendanaan (Money), Sumber Daya Alam (Mother Nature), 
Metode (Method) Bahan Utama (Material) dan Pemasaran (Marketing). Data hasil dari analisis SWOT disajikan pada tabel dibawah ini :

Tabel 2 Tabel Analisis SWOT Kondisi Desa Brajan Berdasarkan Sumber Daya Manusia (Sumber : Pribadi 2020)

\begin{tabular}{|c|c|c|c|c|}
\hline & $\mathbf{S}$ & $\mathbf{W}$ & 0 & $\mathbf{T}$ \\
\hline Man & \begin{tabular}{|l} 
1. \\
Warga yang \\
relatif sudah \\
terbiasa \\
menerima \\
kunjungan \\
wisata \\
2. Warga yang \\
sebagian \\
mempunyai \\
ketrampilan \\
dalam mengolah \\
komoditas \\
bambu \\
Warga yang \\
sebagian sudah \\
mempunyai \\
showroom \\
kerajinan bambu
\end{tabular} & $\begin{array}{l}\text { Kelompok yang } \\
\text { berkembang adalah } \\
\text { yang fokus pada } \\
\text { perdagangan } \\
\text { kerajinan bambu, } \\
\text { sedangkan } \\
\text { kelompok yang } \\
\text { mengelola kegiatan } \\
\text { wisata lain relatif } \\
\text { tidak aktif }\end{array}$ & $\begin{array}{l}\text { Partisipasi dan } \\
\text { kerja sama warga } \\
\text { desa masih dapat } \\
\text { ditingkatkan }\end{array}$ & $\begin{array}{l}\text { 1. Ada potensi } \\
\text { ketidak } \\
\text { kompakan } \\
\text { antar warga } \\
\text { terkait } \\
\text { kegiatan } \\
\text { wisata desa } \\
\text { 2. Sikap apatis } \\
\text { warga desa } \\
\text { yang selama } \\
\text { ini tidak } \\
\text { mendapatkan } \\
\text { keuntungan } \\
\text { dari kegiatan } \\
\text { wisata }\end{array}$ \\
\hline Money & & $\begin{array}{l}\text { Pemasukan dana } \\
\text { kas desa yang } \\
\text { masih kecil }\end{array}$ & $\begin{array}{l}\text { 1. Pemasukan dari } \\
\text { kedatangan } \\
\text { pengunjung } \\
\text { 2. Bantuan } \\
\text { pembiayaan dari } \\
\text { pemerintah } \\
\text { 3. Kas desa }\end{array}$ & $\begin{array}{l}\text { 1. Lamanya masa } \\
\text { pandemi yang } \\
\text { menyebabkan } \\
\text { pemasukan } \\
\text { dari kunjungan } \\
\text { wisata } \\
\text { berkurang } \\
\text { drastis. } \\
\text { 2. Muncul } \\
\text { resistensi dari } \\
\text { desa tetangga } \\
\text { berkaitan } \\
\text { dengan } \\
\text { ketimpangan } \\
\text { keuntungan } \\
\text { secara } \\
\text { ekonomi dari } \\
\text { kegiatan } \\
\text { wisata di Desa } \\
\text { Brajan }\end{array}$ \\
\hline $\begin{array}{l}\text { Mother } \\
\text { Nature }\end{array}$ & $\begin{array}{l}\text { 1. Lingkungan } \\
\text { alam desa } \\
\text { mendukung } \\
\text { konsep } \\
\text { ecotourism } \\
\text { 2. Lingkungan } \\
\text { alam desa sekitar } \\
\text { dan rute menuju } \\
\text { Desa Brajan juga } \\
\text { mendukung } \\
\text { konsep } \\
\text { ecotourism }\end{array}$ & $\begin{array}{l}\text { 1. Fasilitas taman } \\
\text { bunga yang } \\
\text { cenderung } \\
\text { kurang } \\
\text { diperhatikan } \\
\text { pengelolaannya } \\
\text { 2. Semakin } \\
\text { berkurangnya } \\
\text { sumber utama } \\
\text { tanaman yang } \\
\text { dijadikan bahan } \\
\text { utama } \\
\text { keunggulan desa, } \\
\text { yaitu pohon } \\
\text { bambu }\end{array}$ & 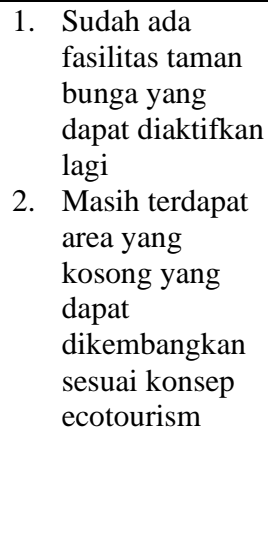 & $\begin{array}{l}\text { Pembangunan } \\
\text { yang kurang } \\
\text { memperhatikan } \\
\text { fungsi konsep } \\
\text { wisata ecotourism }\end{array}$ \\
\hline Method & 1. Pendayagunaan & Belum adanya & Area yang kosong & Persaingan \\
\hline
\end{tabular}




\begin{tabular}{|c|c|c|c|c|}
\hline & $\begin{array}{l}\text { komoditas } \\
\text { bambu seperti } \\
\text { perdagangan } \\
\text { kerajinan bambu } \\
\text { dan pelatihan } \\
\text { membuat } \\
\text { kerajinan bambu } \\
\text { 2. Pendayagunaan } \\
\text { kekhasan } \\
\text { lingkungan alam } \\
\text { pedesaan }\end{array}$ & $\begin{array}{l}\text { program wisata } \\
\text { terpadu dengan } \\
\text { konsep yang ditata } \\
\text { sesuai dengan } \\
\text { kekhasan Desa } \\
\text { Brajan }\end{array}$ & $\begin{array}{l}\text { dapat ditambahkan } \\
\text { fasilitas fisik } \\
\text { dengan ciri khas } \\
\text { bambu Desa Brajan } \\
\text { sebagai daya tarik } \\
\text { baru kunjungan } \\
\text { wisata }\end{array}$ & $\begin{array}{l}\text { dengan desa } \\
\text { wisata lain } \\
\text { dengan konsep } \\
\text { wisata yang lebih } \\
\text { mapan }\end{array}$ \\
\hline Material & Komoditas bambu & $\begin{array}{l}\text { Tanaman bambu } \\
\text { sebagian besar } \\
\text { sudah harus } \\
\text { didatangkan dari } \\
\text { luar desa }\end{array}$ & $\begin{array}{l}\text { Mengembangkan } \\
\text { komoditas bambu } \\
\text { tidak hanya sebatas } \\
\text { kerajinan }\end{array}$ & $\begin{array}{l}\text { Kualitas bambu } \\
\text { di musim hujan } \\
\text { yang kadang } \\
\text { kurang bagus } \\
\text { (bebintik hitam) }\end{array}$ \\
\hline Marketing & $\begin{array}{l}\text { Sudah dikategorikan } \\
\text { sebagai desa wisata }\end{array}$ & $\begin{array}{l}\text { Belum adanya } \\
\text { inovasi untuk } \\
\text { 'menjual' } \\
\text { keunggulan } \\
\text { kompetitif desa }\end{array}$ & $\begin{array}{l}\text { Tren wisata luar } \\
\text { ruangan pada masa } \\
\text { pandemi yang dapat } \\
\text { difasilitasi dengan } \\
\text { wisata ecotourism }\end{array}$ & $\begin{array}{l}\text { Masa pandemi } \\
\text { yang panjang } \\
\text { yang berpengaruh } \\
\text { pada aktivitas } \\
\text { kegiatan } \\
\text { pariwisata }\end{array}$ \\
\hline
\end{tabular}

\subsection{Ideation}

Ideation merupakan tahapan yang mengharuskan untuk melakukan brainstorming dengan cara berpikir secara bebas dan luas sehingga menghasilkan ide solusi secara acak. Setelah menghasilkan ide kemudian menyaring dan mengelompokkan ide-ide tersebut. Ideation merupakan hasil dari interpretation yang dalam penelitian ini berupa susunan strategi guna memperkuat karakter yang selama ini sudah dimiliki Desa Wisata Brajan. Strategi ini dianggap layak untuk dilakukan karena potensi utamanya sudah dimiliki oleh Desa Brajan, yaitu lingkungan fisik berupa alam pedesaan dan lingkungan non fisik yaitu warga yang sudah terbiasa menerima kunjungan wisata dengan berbagai aktivitasnya. Hal yang perlu dilakukan untuk mengembangkannya adalah dimulai dengan melakukan kajian tentang potensi yang dimiliki Desa Brajan.

Berdasar hasil analisis data tergambar bahwa Desa Wisata Brajan memiliki cukup potensi untuk dikembangkan sebagai destinasi wisata ecotourism. Potensi yang dimiliki tersebut saat ini sebagian sedang mengalami kesulitan karena terdampak pandemi COVID-19. Dampak paling utama adalah berkurangnya jumlah kunjungan wisata sehingga pengembangan baik fasilitas maupun aktivitas wisata menjadi turut terhambat. Terdapat beberapa kesulitan tetapi masih besar harapan bahwa potensi yang dimiliki Desa Brajan jika dikembangkan dengan strategi yang tepat akan dapat mengatasinya.

Strategi yang dimaksud dalam hal ini adalah pengembangan melalui konsep wisata ecotourism yang tujuannya adalah memperkuat karakter yang selama ini sudah dimiliki Desa Brajan agar dapat berjalan secara berkelanjutan (Alisjahbana \& Murniningtyas, 2018). Hal ini dianggap layak untuk dilakukan karena potensi utamanya sudah dimiliki oleh Desa Brajan, yaitu lingkungan fisik berupa alam pedesaan dan lingkungan non fisik yaitu warga yang sudah terbiasa menerima kunjungan wisata dengan berbagai aktivitasnya. Hal yang perlu dilakukan untuk mengembangkannya adalah dimulai dengan melakukan kajian tentang potensi yang dimiliki Desa Brajan.

Hasil dari kajian adalah susunan kriteria tentang fasilitas dan aktivitas yang mesti dipenuhi agar konsep wisata ecotourism dapat dijalankan dengan baik, dengan uraian sebagai berikut :

1. Menyatu dan Harmonis 
Kriteria menyatu dan harmonis dapat dijelaskan sebagai rumusan bahwa pengembangan wisata mesti mempunyai kesesuaian dengan apa yang sudah dirintis dan dikembangkan di Desa Wisata Brajan. Pengembangan juga harus menyatu dan harmonis dengan kekhasan utama desa yaitu komoditas bambu dan lingkungan alam pedesaan, yang selanjutnya akan dapat dikembangkan menjadi wisata ecotourism.

\section{Aman dan Nyaman}

Kriteria yang kedua ini dirumuskan karena pada masa pandemi COVID-19 ini diperlukan fasilitas yang mampu memenuhi protokol kesehatan dan mengakomodir kebutuhan masyarakat untuk beraktivitas. Protokol yang ketat tentu saja tidak akan membuat nyaman banyak orang, untuk itulah kriteria keamanan yang dibangun mesti juga menyertakan kenyamanan. Tujuannya adalah membuat warga dan pengunjung merasa lebih rileks dalam menjalani aktivitasnya, tanpa abai terhadap protokol kesehatan yang berlaku.

3. Swakelola.

Sejauh ini warga Desa Brajan sudah menjalankan berbagai aktivitas baik berupa perdagangan komoditas kerajinan bambu maupun aktivitas wisata lainnya. Kriteria swakelola penting untuk dirumuskan karena pengembangan wisata desa membutuhkan keterlibatan warga secara aktif karena pihak yang paling berkepentingan untuk pengembangan adalah warga desa sendiri.

4. Kemudahan Akses Informasi

Kriteria selanjutnya adalah tentang kemudahan akses, yang dalam hal ini dimaksudkan sebagai kemudahan akses informasi tentang keberadaan wisata di Desa Brajan, yang meliputi juga upaya untuk mempromosikannya. Selain kemudahan informasi tentang rute mesti juga dikembangkan kemudahan memperoleh akses informasi tentang Desa Brajan. Kemudahan ini berupa promosi dengan metode yang saat ini medianya. relatif mudah untuk dikembangkan. Kerja sama dengan biro wisata ataupun melalui media online adalah metode yang dapat mempermudah wisatawan untuk mengetahui kekhasan Desa Brajan.

5. Pengembangan Lingkungan

Kriteria terakhir adalah pengembangan lingkungan baik yang berupa fasilitas fisik maupun lingkungan alam, yang diyakini dapat mendukung konsep ecotourism di Desa Brajan. Pengembangan yang dimaksud adalah dapat berupa penambahan, reaktivasi atau perbaikan yang sebelumnya sudah dimiliki. Fasilitas pertama yang mesti diperbaiki adalah akses jalan beserta petunjuk rute menuju Desa Brajan. Selanjutnya yang perlu diperhatikan lagi adalah fasilitas yang selama ini sudah eksis tetapi kurang tergarap dengan baik, sehingga relatif tidak mendukung pengembangan konsep ecotourism. Pemanfaatan area tertentu yang relatif belum atau kurang tergarap adalah suatu rumusan yang cukup taktis untuk mengoptimalkan potensi yang sudah dimiliki desa. Pengembangan yang juga penting dalam konsep ecotourism adalah pemanfaatan lingkungan. Konsep ecotourism mensyaratkan lingkungan yang mampu menghadirkan suasana alam yang membuat pengunjung merasakan rileks serta merasa terbebas dari rutinitas kesibukan kesehariannya.

\section{Simpulan}

Berdasar penelitian yang telah dilakukan penulis membagi kesimpulan menjadi dua, yaitu : 
1. Kesimpulan umum, yang menjelaskan bahwa konsep wisata ecotourism sebenarnya sebagian sudah dilaksanakan di Desa Wisata Brajan, tetapi memang konsep ini belum dikembangkan secara terfokus dan sistematis. Kondisi demikian menyebabkan aktivitas wisata yang selama ini ada relatif belum dapat dikembangkan secara optimal karena ada beberapa aktivitas wisata yang kurang sinambung satu sama lain serta pengelolaannya yang kurang digarap secara serius.

2. Kesimpulan khusus, menjelaskan secara lebih rinci tentang kriteria-kriteria yang dibutuhkan untuk pengembangan konsep wisata ecotourism seperti digambarkan dalam kesimpulan umum, yaitu :
a. Menyatu dan harmonis.
b. Aman dan nyaman.
c. Swakelola.
d. Kemudahan akses informasi.
e. Pengembangan lingkungan.

Kriteria seperti dihasilkan dalam penelitian tersebut adalah yang selanjutnya dapat digunakan sebagai dasar strategi pengembangan konsep wisata ecotourism di Desa Wisata Brajan.

\section{Daftar Pustaka}

Alisjahbana, A. S., \& Murniningtyas, E. (2018). Tujuan Pembangunan Berkelanjutan Di Indonesia (Konsep, Target Dan Strategi Implementasi). Bandung: Unpad Press.

Design Thinking for Educators. (2013). Diambil kembali dari IDEO: https://www.ideo.com/post/design-thinking-for-educators

Handayani, D., Hadi, D. R., Isbaniah, F., Burhan, E., \& Agustin, H. (2020). Penyakit Virus Corona 2019. Jurnal Respirologi Indonesia, 119-129. http://jurnalrespirologi.org/index.php/jri/article/view/101

Jones, D. L. (2008). Environmentally Responsible Design: Green and Sustainable Design for Interior Designers. . New Jersey: John Wiley \& Sons.

Liliana, L. (2016). A New Model of Ishikawa Diagram for Quality Assessment. Materials Science and Engineering. IOP Conference Series: Materials Science and Engineering (hal. 1-6). Kozani, Greece: IOP Publishing. https://doi.org/10.1088/1757-899X/161/1/012099 